\title{
K-RAS ASP-12 Mutant Protein
}

National Cancer Institute

\section{Source}

National Cancer Institute. K-RAS ASP-12 Mutant Protein. NCI Thesaurus. Code C29135.

A mutant form of the p21-ras protein transcribed from a mutant form of the oncogene $\mathrm{K}$-ras. K-Ras is located in the plasma membrane and transduces growth and differentiation signals from activated receptors to protein kinases within the cell. K-RAS ASP-12 contains a mutation at codon 12 and may be used in cancer immunotherapy. $(\mathrm{NCl04})$ 